\title{
Deconstructing the native fish strategy for Australia's Murray Darling catchment
}

\author{
J. Marohasy \& J. Abbot \\ Centre for Plant and Water Science, CQ University, Australia
}

\begin{abstract}
The Murray is Australia's longest river and drains a catchment of over 1 million square kilometres. Before sea dykes were built across the five channels that converge on the Murray's sea mouth in the 1930s, mulloway, Agyrosomus japonicas, were a mainstay of the local fishery. Back then, Lake Alexandrina was the central basin of a barrier estuary. Now, the lake is managed as a freshwater reservoir and there are no mulloway. This history is, however, ignored in the Australian Commonwealth government's Native Fish Strategy for the Murray Darling Basin 2003-2013. There is no mention of mulloway in The Strategy, yet its overriding objective is ostensibly the restoration of fish populations.

In this study, progress in implementation of The Strategy is reviewed, ten years after its inception. It is suggested that despite significant expenditure The Strategy has failed in key areas. In 2003, when The Strategy was launched it explained native fish numbers were at $10 \%$ of pre-European settlement levels (before 1788). This may still be the case. Even for flagship species like Murray cod, Maccullochella peelii, there remains no data on the contribution of a significant restocking effort to recruitment. It is concluded that water quality remains a key issue, in particular, cold-water pollution in the upper reaches and the absence of a salt-water gradient in the lower Murray.

Keywords: restoration, Australian native fish, Murray River, Murray Darling catchment, Maccullochella peelii, Argyrosomus japonicas.
\end{abstract}




\section{Introduction}

\subsection{Water reform in Australia}

The Murray Darling catchment, also known as the Murray Darling basin, drains an area of over one million square kilometres in south eastern Australia (fig. 1). The catchment includes the Australian Alps that provide reliable snow melt, arid plains, and is subject to six jurisdictions that would each like to maximise their access to the water resource. Significant water infrastructure development has occurred in the catchment and this has resulted in a reduction in the amount of water that flows out to sea in the state of South Australia from an average of approximately 13,000 gigalitres to 5,000 gigalitres [1]. Using averages, however, can be deceptive in a catchment of extremely variable annual inflows that have ranged from a high of approximately 117,907 gigalitres in 1956 to only 6,749 gigalitres in 2006.

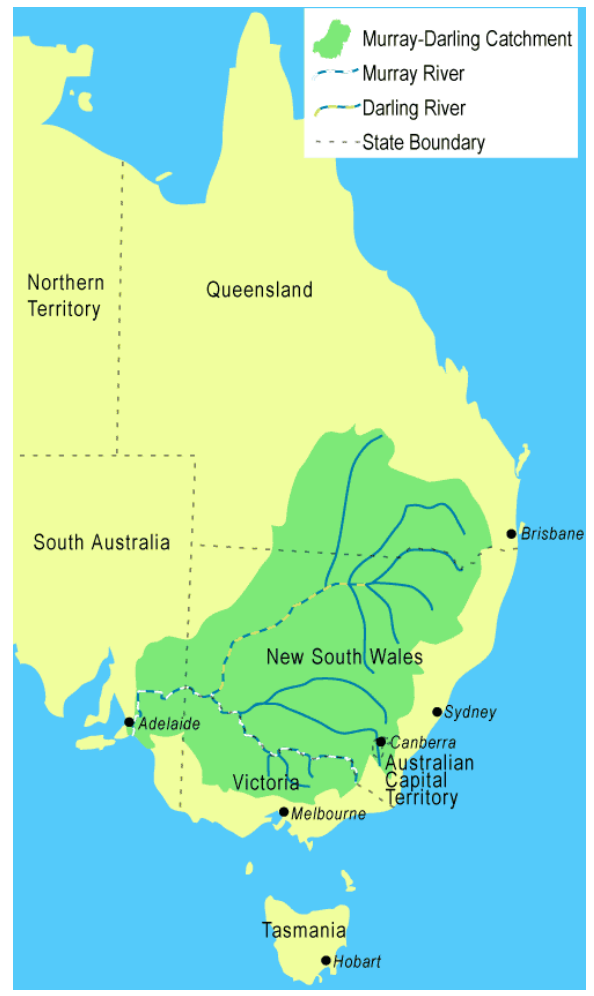

Figure 1: Murray Darling catchment, also known as the Murray Darling Basin (Image from Wikipedia).

Water reform over the last two decades has focused on the redistribution of water from irrigated agriculture to the main channel of the river in particular to 
increase end-of-system flows. This redistribution is variously described as improving environmental outcomes, increasing environmental water and environmental waterings. In Australia agriculture is not seen as part of the environment, but as in competition with the environment particularly for the water resource. Addressing this issue, federal legislation under the Commonwealth Water Act 2007 required the Murray Darling Basin Authority (MDBA) develop a Basin Plan. This plan, that became legislation in November 2012, specifies a maximum sustainable quantity of water that can be used for irrigated agriculture.

The Native Fish Strategy for the Murray-Darling Basin 2003-2013 [2], henceforth referred to as The Strategy, was an initiative based on many of the same assumptions underpinning the new Basin Plan and administered by the same authority, the MDBA. Edition 34 of RipRap, a publication of the Australian River Restoration Centre details many of the achievements of The Strategy. The many and varied articles in this publication laud The Strategy as providing a coordinated and scientific approach to the rehabilitation of fish populations. It is also stated that native fish populations are still in decline and remain at only about $10 \%$ of estimated levels before European settlement [3]. This is the same percentage estimated in 2003, when The Strategy was launched.

\subsection{Trends and objectives}

The Strategy, launched in May 2003, estimated native fish populations to be at about $10 \%$ of their pre-European settlement levels. In Australia, pre-European generally refers to the period before 1788 . The objective of The Strategy was to return native fish populations to $60 \%$ of their pre-European levels by 2050 [2]. No interim targets were established, and no targets set for specific fish species. The plan was ostensibly about generally increasing native fish numbers. In this deconstruction of The Strategy we focus on population numbers of two native fish species, Murray cod, Maccullochella peelii, and mulloway, Argyrosomus japonicus. Both species were once part of significant commercial fisheries in the Murray River.

Estimates that native fish populations are at $10 \%$ of their pre-European levels are based on the advice of an expert panel, rather than any quantitative assessment [4]. The Strategy provides a chart showing the decline in the catch of Murray cod between 1947 and 1996. Mention is made that the chart shows "the naturally variable nature of fish populations" and "the loss of most commercial fisheries". The Strategy, however, does not explain that the amount of fishing changed over the period shown in the chart or that the commercial catch showed some improvement in the 1990s, up until its closure [5].

In 2003, when The Strategy was launched, a survey of fish undertaken by The Cooperative Research Centre for Freshwater Ecology (Australia) in conjunction with the New South Wales government was considered the most comprehensive survey of fish abundance in the Murray-Darling [6]. This report's principal conclusions included comment that: "A telling indication of the condition of rivers in the Murray region was the fact that, despite intensive fishing with the most efficient types of sampling gear for a total of 220 person-days over a two- 
year period in 20 randomly chosen Murray-region sites, not a single Murray cod or freshwater catfish was caught.” This apparent absence of Murray cod was perhaps a reflection of the fishing methods of the scientists, given the commercial harvest for the same region for the same period was 26 tonnes of Murray cod [5].

The same year The Strategy was launched, an annual fishing competition - the Deniliquin Yamaha Fishing Classic - registered a record 48 Murray cod in 2003. A feature article in the winter 2003 edition of Freshwater Fishing Australia entitled Riverina Revival included comment that, "The mainstay of the Edward River fishery [an anabranch of the Murray] is the Murray cod and numbers at present are high... the number of juvenile fish of $45-50 \mathrm{~cm}$ just short of legal length of $50 \mathrm{~cm}$, can be frustratingly high for anglers looking for a keeper."

But what is "high" if there is no established and relevant benchmark? The Australian government has spent money on "auditing" fish numbers, but the auditing only provides a "snapshot" for specific rivers at particular points in time, with the reporting couched in the subjective criteria of 'good', 'moderate', 'poor' and 'very poor' with the later criteria dominating [7]. During the most recent audit, fish were sampled at 510 sites that yielded more than 63,000 individuals from 36 species (27 native, 9 alien), weighing around 4.5 tonnes (1.5 tonnes native, 3 tonnes alien). The audit reported that Murray cod recruits were observed at more than half of the 97 sampling sites at which the species was recorded. The audit, however, makes no determination as to whether the very significant Murray cod re-stocking program is having a positive impact on fish population numbers. In a recent study of the impact of stock enhancement strategies for Murray cod on effective population size, Ingram [8] report that 12.89 million Murray cod have been produced at both government and private (commercial) hatcheries since 1971, but conclude that "there is no information on the survival of stocked fish to maturity."

Murray cod is endemic to the Murray-Darling and is apparently one of the largest freshwater fish in the world reaching a highest recorded weight of 113.6 $\mathrm{kg}$ and an age estimate between 74-114 years. There are currently no commercial fishing licences for Murray cod in Australia. The wild catch industry had ceased by 2004 in all Australian states following intense lobbying from recreational fishers and environmentalists.

\subsection{The estuary}

There are no longer mulloway in Lake Alexandrina and no intention to restore this once important mulloway habitat to estuarine [9]. There is no mention of mulloway in The Strategy and it is not listed in any tables or appendices [2]. Estuaries are important to rivers. In The Strategy, however, there is only one mention of the word estuary, and only by reference to 'estuary perch', which is listed as "uncommon in the Lower River Murray".

A mature mulloway can be 25 years old and weigh 90 pounds. Milang, a town on the shores of Lake Alexandrina that was once part of the Murray River's vast estuary [10], was once home to a thriving mulloway fishery supporting a hundred men and their families routinely sending off several hundred tons to the 
Adelaide and Melbourne fish markets. This fishery collapsed in 1940 when the last of five sea dykes was sealed, converting the tidal lake into an artificial freshwater reservoir [11].

\section{Priority works}

The Strategy explains that it seeks to target the causes as well as the symptoms of declining native fish populations and to be focused on "long-term rehabilitation rather than restoration" [2]. The Strategy provides a "10-year framework" building on the principles of a plan first developed in 1991, Fish Management Plan for the Murray River. The Strategy explains that only through a combination of interventions could native fish communities be restored to $60 \%$ of pre-European (before 1788) levels but The Strategy also details how specific interventions alone, and in combination, could make a significant positive impact (fig. 2). These five interventions, also referred to as priority works, are considered, with particular reference to Murray cod and mulloway.

\subsection{Habitat restoration}

The Strategy explains that through habitat restoration alone, native fish populations could be restored to $25 \%$ of pre-European levels. The Strategy, however, completely ignores consideration of the need to restore the Murray River's estuary that once included important breeding grounds and nursery areas for both the mulloway and Murray cod. The Strategy states: "A diversity of habitats is needed for a diversity of species and life stages. In-stream and riparian habitats within the Basin have been severely degraded by factors such as river desnagging (removal of dead tree trunks and branches), loss of wetland, floodplain and river connectivity, bank erosion and sedimentation.”

An initial focus of The Strategy was resnagging 194 kilometres of river immediately downstream of Hume dam with 4,500 new snags (logs with embedded microchips). Seven years of data collection suggests that this effort has resulted in the migration of native fish into this area, including Murray cod. However, it is unclear whether there has been successful breeding of Murray cod in this stretch of river [12]. In fact given the cold-water pollution issues (discussed in section 2.5), the resnagging of this stretch of the river could have caused net migration of Murray cod into an area unsuitable for the breeding of this species.

In the northern catchment there have been many 'Demonstration Reaches' established with work in the Namoi, for example, including the reintroduction of 300 snags, 5,700 aquatic plants, 9,000 native trees and shrubs, 33.4 kilometres of woody weed management, 33.5 kilometres of riparian fencing, installing 20 offstream watering points and eight in-stream gully and erosion protection works [13]. 


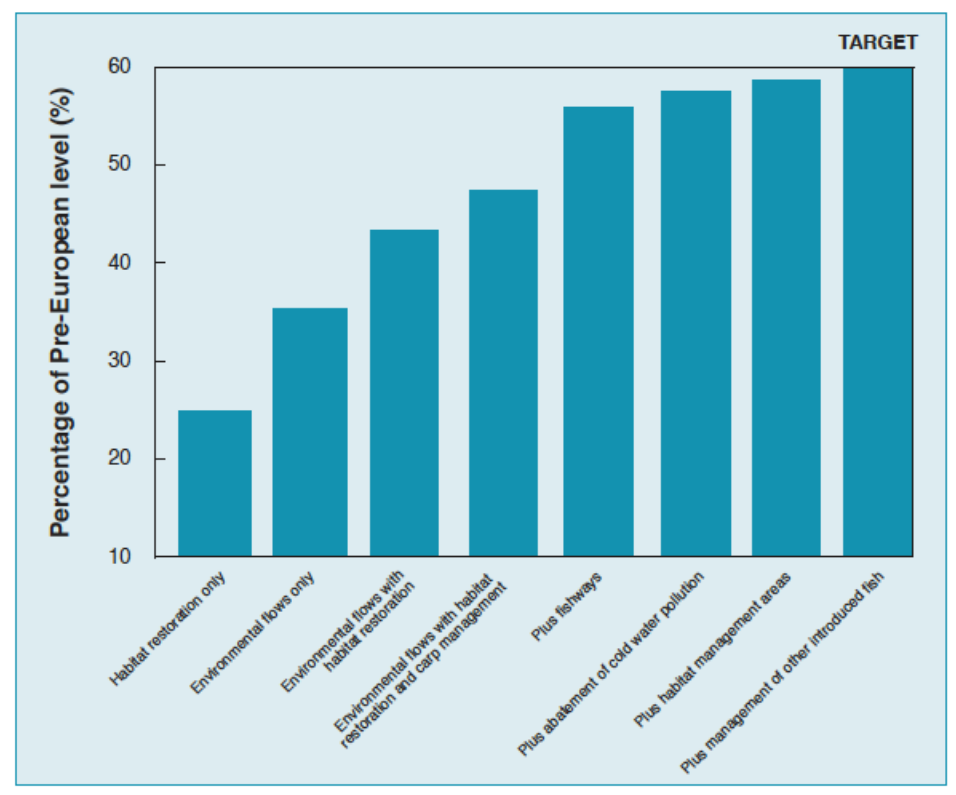

Figure 2: $\quad$ Rehabilitation of native fish communities - cumulative impact of all interventions.

\subsection{Environmental flows}

The Strategy explains that environmental flows alone could return native fish to $35 \%$ of their pre-European (before 1788) level, yet no benefit has been reported from this intervention. Environmental flows are a focus of the new Basin Plan that has as its target the recovery of 2,750 gigalitres of water as environmental flow. In 2002, at the time The Strategy was being developed, the environmental flow target was much more modest. Indeed in April 2002, when the MurrayDarling Basin Ministerial Council called for social, economic and ecological assessments of the costs and benefits of returning additional environmental water to the River Murray three flow volumes were chosen - 350, 750 and 1,500 GL per year - as 'reference points' for assessment. Significant lobbying underpinned by a group sponsored by the World Wide Fund for Nature result in the higher final target of 2,750 gigalitres being adopted in the new Basin plan [9].

As at 30 September 2012, the MDBA reported that the water purchase program had already secured entitlements that will deliver, on average, 1,094 gigalitres of water each year worth $\mathrm{A} \$ 2.27$ billion ( $€ 1.79$ billion equivalent). The MDBA has also reported that more than 1,327 gigalitres of Commonwealth environmental water has been delivered. In October 2005, the Victorian government reported that 513 gigalitres of water was delivered into the BarmahMillewa, red gum forest in one watering "triggering large reproductive events in important native fish species such as golden perch and the threatened silver perch”. 


\subsection{Carp management}

The Strategy explains that the pest European carp, Cyprinus carpio, make up an estimated 60 to 90 per cent of the total fish biomass at many sites, with densities as high as one carp per square metre of river surface area. Through the combination of environmental flows, habitat restoration and carp management The Strategy suggests that native fish could be returned to $45 \%$ of their preEuropean levels (fig. 2).

If stretches of river had been allowed to completely dry out during the recent Millennium drought that lasted from 2002 to 2009, carp numbers would have been dramatically reduced. Murray cod, and other native species, can survive extended periods of dry conditions by burrowing and then hibernating in dry riverbeds. Carp, in contrast, are left stranded and die.

In the lower reaches of the Murray River, carp could have been completely eliminated by letting the Southern Ocean penetrate a significant distance up the main channel as once happened naturally during drought before construction of the sea dykes.

There is an historical photograph in the State Library of South Australia of a porpoise caught at Tailem Bend in 1927. Tailem Bend is approximately sixty kilometres upstream of the River Murray's sea mouth. The caption for the photograph reads: "In his reminiscences of growing up and working as a fisherman on the River Murray, Doug Hattam recalled how during a period of drought in 1926, the waters of the Murray became saline as far upstream as Murray Bridge. Before the barrages were built between 1935 and 1940, saltwater could reach as far upstream as 250 kilometres from the Murray Mouth, and river levels could fluctuate considerably. In 1926, two porpoises were found to be living in the salty water around the Tailem Bend area. The porpoises lived there for several months, until the freshwater returned. One of them died at Tailem Bend before it was able to return to the sea. It was common to refer to the creatures as 'porpoises', but it is now thought that they could have been a variety of pygmy whale.”

It would now be physically impossible for pygmy whales to enter Lake Alexandrina because of the sea dykes. During the worst of the recent Millennium drought, water levels were allowed to fall in Lake Alexandrina to below sea level ostensibly to 'protect' existing freshwater habitat in Lake Alexandrina [14]. This government policy was supported by the significant commercial carp industry in the Lower Murray. Hundreds of tonnes of carp are commercially harvested every year from Lake Alexandrina and converted into plant fertilizer with the commercial catch in the Lower Murray in 2008/2009 reported as 792 tonnes worth A\$863,000 (€681,000 equivalent) [15].

\subsection{Fishways}

The Sea to Hume Dam project was an A\$60 million (€47.69 million equivalent) initiative with the objective of providing a continuous passage for fish from the mouth of the Murray to the Hume Dam, a distance of 2,225 km [16]. The project was due for completion in 2010 at which time it was anticipated that there would 
be 14 new fishways on 12 weirs and five barrages along the main stem of the Murray [17]. In 2012 the project was hailed as a success and selected as one of the top 25 Australasian ecological restoration projects by a panel set up by the journal Ecological Management and Restoration. Ten fishways have been completed, with the remaining four due for completion by June 2013 [18].

According to The Strategy adding fishways as an intervention in addition to environmental flows, habitat restoration and carp management would result in the rehabilitation of native fish communities to about $55 \%$ of pre-European levels (fig. 2). There has been no evaluation of the overall contribution of the fishways to the rehabilitation of native fish numbers but it believed that the fishways are already successfully providing important passage to native fish along the main stem of the Murray River and that by June 2013 there will be continuous passage for 2,200 kilometres [18].

Millions of dollars have been spent putting fishways into the concrete walls of the five sea dykes immediately behind the Murray River's mouth. Mulloway, and most other marine and estuarine fish species, however, need more than a passage to successfully migrate upstream: they need a saltwater gradient.

\subsection{Cold water pollution abatement}

Cold-water pollution occurs when water is released from the bottom of deep reservoirs that are thermally stratified. Most native fish species in the Murray Darling, including Murray cod, require relatively warm water temperatures to induce spawning. Studies undertaken during the 1980s, and the 1990s [19, 20], indicate that frequent large releases of water for irrigation from the Hume and Burrinjunk dams occur in spring and early summer which are also critical times for spawning of key native fish species. Releases from Hume dam can lower water temperatures by up to $7^{\circ} \mathrm{C}$ [19]. The impact of these releases on Murray cod varies with the magnitude and timing of the water releases [20]. Lugg [21] showed that temperatures downstream of Burrinjuck dam on the Murrumbidgee River seldom approach levels required for spawning of key native species.

The expert panel that oversaw development of The Strategy were confident that the abatement of cold water pollution was the most tangible and achievable of all the proposed interventions to the extent that this "threat could be largely removed from the Basin within 10 years" [4]. The Hume and Burrinjuck dams, like most of the dams through the Murray Darling, have the outlets for irrigation positioned at depth creating a jet of cold water. Government commissioned reports [e.g. 20] have considered different techniques for cold water abatement including retrofitting with multi-level outlets, artificial destratification through mechanical mixing, trunnions (pipes hinged at the outlet drawing water from different levels), surface pumps (large fan-like propellers that pump warm surface water into existing outlets), and submerged rubber curtains to stop the flow of cold water to the outlets.

The Strategy includes the comment: "it [cold water pollution abatement] appears to be a clearly definable, tangible, cost-effective intervention that can be completed for the major storages in the Basin within ten years, through a combination of engineering and operating changes.” Many workshops, technical 
papers and government reports have been written since the launch of The Strategy [22] none of these contradicting the original advice. A study by Sherman [23] estimated cold-water abatement downstream of Hume dam could be achieved for between A \$5 and A \$20 million - a fraction of the money already spent on The Strategy. However, not a single initiative that will practically address the issue of cold-water pollution has so far been implemented.

\section{Conclusions}

Schedule 1 of the new Basin Plan, legislated in November 2012, refers to the serious decline in the distribution and abundance of native fish as a reflection of the continuing poor state of the river system and the impacts of human use. This is despite significant government funding to improve the natural environment of the Murray Darling catchment over the last decade with an additional A \$10 billion (€7.95 billion equivalent) allocated in 2007 to assist the redistribution of waters from agriculture to the environment.

It is ten years since the launch of The Strategy but nothing has been done to address the issue that was back then, in 2003, considered most pressing and most easily addressed: the issue of cold-water pollution from the Hume dam. In January 2013, the MDBA explained that there are no longer any plans for mitigation of cold-water pollution from Hume Dam [18]. Yet much of the restocking and resnagging effort has focused on the mainstream of the river immediately downstream of the Hume Dam and could be considered futile if the issue of cold-water pollution is not addressed [4]. Can there be any advantage for anyone in not addressing the issue of cold-water pollution abatement?

The Victorian Fly Fisher's Association states on its website that it is an "historical association" with considerable influence in the promotion of the sport and the propagation of trout [24]. Apparently the trout and fly-fishing lobby were initially opposed to The Strategy but this opposition has softened because the issue of cold-water pollution will no longer be addressed and has been removed as an issue from the publicity associated with rehabilitation of key demonstration reaches [e.g. 25].

Predation and competition from introduced salmonids, including brown trout and rainbow trout, has a significant impact on native fish populations throughout southern Australia (Cadwallader [26]). The Strategy explains that the impact of these species would be reduced with cold-water pollution abatement. So, in not addressing the issue of cold-water pollution, not only do key reaches of the Murray and Murrumbidgee rivers remain unsuitable for the breeding of native fish species, but also water quality will remain particularly suitable for introduced trout species that suppress native fish population numbers through predation. The introduced brown trout, for example, is considered a key threat to the recovery of the native trout cod and Macquarie perch [26] and particularly favoured by cold water pollution [2].

The issue of estuary restoration is not even canvassed in The Strategy. During the recent Millennium drought, water levels in Lake Alexandrina fell precipitously from 0.85 metres above sea level to -1.10 metres below. There was 
simply not enough water in upstream storages to supply Lake Alexandrina with freshwater. The MDBA could have demanded that the gates within the sea dykes be opened to let in the Southern Ocean, but instead they supported the claims of environmentalists that upstream irrigation was the key issue and that more water environmental flows were needed.

Billions of dollars of public monies have already been spent ostensibly addressing environmental issues in the Murray Darling over the last decade and even more will be spent in the next decade on the Basin Plan. It is unlikely, however, that populations of native fish, including the iconic Murray cod and mulloway, will benefit in any significant way because key issues, in particular estuary restoration and cold water pollution, continue to be ignored.

\section{Acknowledgement}

This research was funded by the B. Macfie Family Foundation.

\section{References}

[1] Murray Darling Basin Commission, Rivers Losses and End of System Flows Fact Sheet, Canberra, 2003. http://www2.mdbc.gov.au/_ data/page/20/water_resourcesver2.pdf

[2] Murray Darling Basin Ministerial Council, Native Fish Strategy for the Murray-Darling Basin 2003-2013, Murray Darling Basin Commission, Canberra, 63pp. 2004.

[3] Koehn, J., Smart partnerships bring back native fish, RipRap 3-4, pp. 3-4, 2012a.

[4] Phillips, B. (ed) Conceptual model to guide investments for restoring native fish in the Murray-Darling Basin, Report by the expert panel convened by the Murray-Darling Basin Commission, pp. 32, 2002.

[5] Marohasy, J., Myth and the Murray: measuring the real state of the river environment, Institute of Public Affairs, Melbourne, 27 pp. 2003.

[6] Harris, J.H. and Gehrke, P.C., (eds). Fish and Rivers in Stress, The NSW Rivers Survey: NSW Office of Conservation/Cooperative Research Centre for Freshwater Ecology, Sydney/Canberra. 293pp. 1997.

[7] Davies, P., Stewardson, M., Hillman, T., Roberts, J., Thoms, M., Sustainable Rivers Audit 2: The ecological health of rivers in the MurrayDarling Basin at the end of the Millennium Drought (2008-2010), Murray Darling Basin Authority, Canberra, 418 pp. 2010.

[8] Ingram, B.A., Hayes, B. and Rourke, M.L., Impacts of stock enhancement strategies on the effective population size of Murray cod, Maccullochella peelii, a threatened Australian fish, Fisheries Management and Ecology, 18, pp. 467-481, 2011.

[9] Marohasy, J., Save the Murray: Restore the Estuary, The Sydney Papers Online, 15, 2012. 
[10] Bourman, R.P., Murray-Wallace C.V., Belperio, A.P., Harvey N., Rapid coastal geomorphic change in the River Murray Estuary of Australia. Marine Geology 170. pp. 141-168, 2000.

[11] Olsen, A.M. 1991. The Coorong: A Multi-species Fishery. Part 1, History and Development, Fisheries, Research Papers No. 22. Department of Fisheries, South Australia, 1991.

[12] Lyon, J., Resnagging the Murray River, RipRap 3-4, pp. 24-25, 2012.

[13] Hobson, M., Namoi Demonstration Reach, RipRap 3-4, 30 pp. 2012.

[14] Brice, C. Literature review on the ecology of fishes of the Lower Murray, Lower Lakes and Coorong, SARDI Publication No. F2010/000031-1, Henley Beach, South Australia, 2010.

[15] Econsearch, Economic indicators for the Lakes and Coorong fishery 2008/09, Primary Industries and Resources South Australia, Adelaide, 47 pp. 2010.

[16] Craik, W. Murray fishways set world ecosystem restoration standard, Murray Darling Basin Commission, Media Release, 2008.

[17] Barrett, J. (ed) The Sea to Hume Dam: Restoring Fish Passage in the Murray River, Murray Darling Basin Commission, Canberra, 98 pp. 2008.

[18] Towers, I. Personal communication, 8 January 2013, Director, Native Fish Strategy, Murray Darling Basin Authority, Canberra.

[19] Ryan, T., Webb, A., Lennie R., Lyon J., Status of cold water pollution releases from Victorian dams, Department of Natural Resources and Environment, Melbourne, 72 pp. 2001.

[20] Sherman, B.S. Scoping options for mitigating cold water discharges from dams. CSIRO Land and Water, Canberra, 130 pp. 2000.

[21] Lugg, A., Eternal winter in our rivers: addressing the issue of cold water pollution, NSW Department of Fisheries, Nowra, 17pp. 1999.

[22] Koehn, J.D. and Lintermans, M., A strategy to rehabilitate fishes of the Murray-Darling Basin, south-eastern Australia, Endangered Species Research16, pp. 165-181, 2012 b.

[23] Sherman, B., Todd, C.R., Koehn, J.D. and Ryan, T. Modelling the impact and potential mitigation of cold water pollution on Murray cod populations downstream of Hume dam, Australia, River Research and Applications, 23, pp. 377-389, 2007.

[24] Victorian Fly Fisher's Association, http://www.vffa.org.au.

[25] Goulburn Broken Catchment Management Authority, Hollands Creek Demonstration Reach, http://www.gbcma.vic.gov.au/hollandscreek /creek.asp

[26] Cadwallader, P.L. Overview of the impacts of introduced salmonids on Australian native fauna, Australian Nature Conservation Agency, 69 pp. 1996. 